\title{
バリオグラムを用いたAMeDAS気温データの空間代表性に関する解析
}

\author{
波多野和儀・泉 岳樹・中山大地・松山 洋
}

\section{The Spatial Representativity of Temperature Data of AMeDAS as Revealed by the Variogram}

\author{
Kazuyoshi HADANO, Takeki IZUMI, Daichi NAKAYAMA and Hiroshi MATSUYAMA
}

\begin{abstract}
The spatial representativity of the annual mean temperature of AMeDAS is investigated using the variogram. In the variogram, the value called as "range" is regarded as the measure of the spatial representativity. It is found that the annual mean temperature have at least the spatial representativity of $50-100 \mathrm{~km}$. Also, the objective methods for estimating the spatial representativity are proposed; (1) the distance to adapt the variogram model can be determined by the Lepage test, and (2) "ranges" of a variogram with the nested structure can be detected by applying the nested variogram models. These methods are well functioned although the forms of the variograms are different one another. In addition, the following important findings are obtained; (1) "ranges" of variograms are not affected by the station densities, and (2) the nested structure appears when the study area is enlarged.
\end{abstract}

Keywords: 地球統計学(geostatistics)，バリオグラム(variogram)，ラページ検定(Lepage test), 空間代 表性(spatial representativity)，AMeDAS(Automated Meteorological Data Acquisition System)

\section{1.はじめに}

現在，数值モデルを用いて，地球温暖化やヒート アイランドといった様々なスケールの大気現象の再 現が試みられている. そして，数值モデルによるシ ミュレーションの妥当性の検証には様々な観測値が 用いられる。

気象台や測候所が行う気象観測は，広い範囲の大 気現象を代表させるために建造物などの影響を受け にくい露場で観測される，これは，きわめて局所的 な観測値を代表値とさせないための措置であり，あ る程度の空間を代表した値であると考えられる。し かし，観測値が代表する空間スケールに関する知見 は三宅(1973)による雨量の分析以外にほとんど見

波多野: $=192-0397$ 東京都八王子市南大沢 1-1 東京都立大学理学部地理学科地理情報学研究室 Laboratory of GIS, Department of Geography, Tokyo Metropolitan University. 1-1, Minami-Ohsawa, Hachiouji, Tokyo 192-0397, Japan E-mail: h-kadu@mercury.sannet.ne.jp
当たらない.

観測された気温と，数値モデルによる気温が代表 する空間スケールが異なっていては数値モデルの妥 当性の検証やシミュレーション結果についての正し い議論はできない.しかしながらこれまでの研究で は，観測された気温の空間代表性について十分な検 討がなされないまま, 数值シミュレーションの妥当 性の検証が行われてきた。泉ほか (1999)では, AMeDASの観測気温と数値モデルによる計算值の誤 差の要因の1つとして, AMeDASの観測值と計算值 の持つ空間代表性の違いを挙げている.また, Sugawara (2001) では，この問題に対して従来の研 究が採用した手法として，(1) 複数の地点での測定 值を平均することで空間代表値とすること，(2) 比 較的開けた場所において計測された值を代表值とす ること（3）センサ付近の熱的環境を観測地点間で 統一すること，(4)測定值が代表するエリアを特定 
すること,の4つを挙げている，そして：(1)の問 題点として，どの程度の数の観測点を平均すれば空 間代表値として十分なのかが不明である，と指摘し ている.

数值モデルの気温が代表するスケールは水平格子 間隔で表される. 数値モデルの水平格子間隔が, 観 測気温が代表する空間スケールより大きい場合，'観 測気温を数值モデルの格子間隔で集計したものと数 值モデルの格子点值を比較する，逆に，数值モデル の水平格子間隔が，観測気温が代表する空間スケー ルより小さい場合, 数值モデルの結果を観測気温が 代表する空間スケールと同じになるように集計して 比較する．このようにすることで, 両者の気温が代 表する空間スケールが等しくなり正確な議論の助け になると考えられる。

そこで; 本研究では，地球温暖化やヒートアイラ ンドなどで関心の高い気温を対象として，AMeDAS データの空間代表性を明らかにすることを目的とし て解析を行う.

\section{2. 気温の空間代表性}

\section{1 気温の空間代表性の定義}

気温の空間代表性はこれまで戦密な定義はなされ ていないが，幾つかの考え方がある，1つには，観 測器が観測している空間の大きさ，つまり観測器の 応答速度と観測值の平均時間間隔並びに観測器周辺 の空気場の流れ(移流)により決定される空間の大き さである. また, 周辺地形, 土地利用，土地被覆， 人工排熱量をはじめとする気温決定の支配要因の条 件が似ていることに伴い，類似した気温やその日変 化が観測される地域 (一種の等質性空間)を空間の大 きさと考えることもできる：さらに，Sugawara (2001)では, 空気塊のもつエネルギーから空間代表 気温とそのスケールを推定している.

このように，気温の空間代表性を一意に定義する ことは現段階では困難な状況であるが，いろいろな 視点からの研究が必要とされていることは間違いな いであろう。

気温とは異なるが, Liu et al. (2001) は, 地球統計 学でよく用いられるバリオグラムという手法を用い
ることにより，中国における土袞水分データの空間 代表性について論じている．2．2節で詳説するが, バリオグラムにより決定されるレンジという值は, 全データの分散を説明できる距離を表しており，こ の距離はある点の観測値が代表する空間の大きさを 表していると考えることができる.

本研究では, “デー夕解析にあたっての客観性なざ も考慮し，バリオグラムを用いて気温の空間代表性 の問題へアプローチすることにする.

\section{2. バリオグラム}

バリオグラム $\gamma_{s}(h)$ は次の式で表わされる.

$\gamma_{\mathrm{s}}(h)=\frac{1}{2 N(h)} \sum_{i, j}\left(S_{i}-S_{j}\right)^{2}$

ここで, $N(h)$ は地点間の距離がんである観測地点ぺ

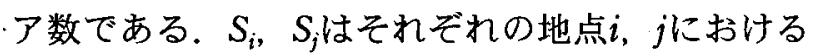
観測値である.

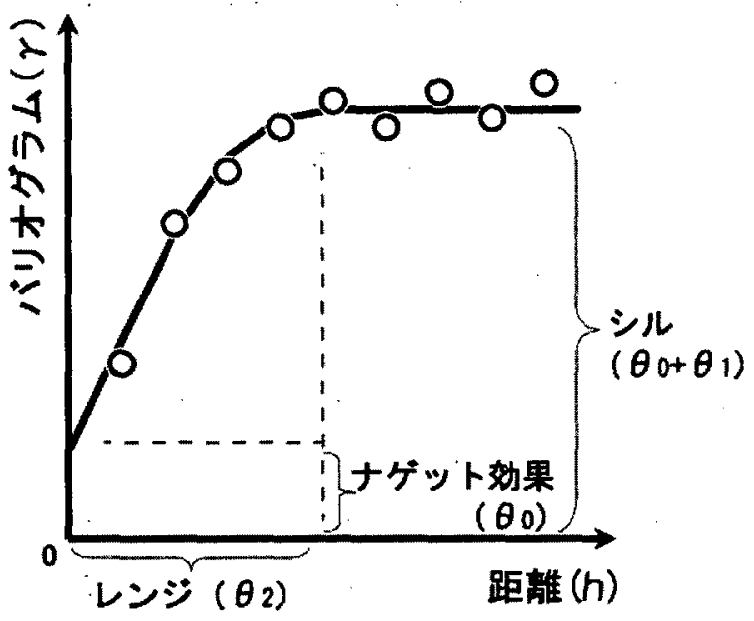

図 1 典型的なバリオグラム

(間瀨·武田，2001 を元に作成）

典型的なバリオグラムは図 1 のような形をとり (間瀬・武田, 2001)，以下のような特徵がある. 距 離 $h$ が 0 のときのバリオグラムの值はナゲット効果 $\left(\theta_{0}\right)$ と呼ばれる.この值は理論上は 0 となるが, 観 測データからは把握不可能な変動や測定誤差によっ て実際は 0にならない。 また,バリオグラムが距離 に対して一定になる值のことをシル $\left(\theta_{0}+\theta_{1}\right)$ と呼び, 理論上は全データの分散と等しくなる。バリオグラ ムが一定になる距離のことをレンジ $\left(\theta_{2}\right)$ と呼ぶ.レン 
ジとはそれまでの距離でデータの全分散を説明でき ることを意味しており, 変動性はレンジを越えると 距離に依存しなくなる. シルやレンジが存在するこ とは, 空間で関係付けられる変動性が存在すること を表している(Liu et al., 2001).

実際にレンジ，ナゲット効果，シルなどを定量的 に求めるためには，バリオグラムにモデルを当ては める必要がある.ここでは, 最も一般的に用いられ る球型モデル (Chiles and Delfiner, 1999)を, 観測値か ら得られたバリオグラムに当てはめることで, 空間 代表性を客観的に求めることができると考えられる.

球型モデルは, 以下の式で表される.

$\gamma_{t}(h)=\left\{\begin{array}{lr}\theta_{0}+\theta_{1} \times\left\{\frac{3 h}{2 \theta_{2}}-\frac{1}{2} \times\left(\frac{h}{\theta_{2}}\right)^{3}\right\}, & \left(0 \leq h \leq \theta_{2}\right) \\ \theta_{0}+\theta_{1}, & \left(h \geq \theta_{2}\right)\end{array}\right.$ . . (2)

ここで, 球型モデルのパラメータ $\left(\theta_{0}, \theta_{1}, \theta_{2}\right)$ を決定 するために次の最小二乗基準

$\sum\left(\gamma_{s}(h)-\gamma_{t}(h)\right)^{2} \longrightarrow \min \quad \cdots$

を用いる.

\section{3. 使用データと研究対象領域}

\section{1 AMeDASデータ}

本研究では気温データとしてAMeDASを用いる. その理由として，入手が容易であり，均質なデータ が日本全国に均等に分布し，かつ長期間存在するこ とが挙げられる。

AMeDASで 4 要素 (降水量, 気温, 風向・風速, 日照時間)を観測している地点の全国平均間隔は約 $21 \mathrm{~km}$ (日本気象学会, 1998)である. 本研究では, AMeDASデータから，1990年から1999年までの気 温デー夕を用いて年平均気温の準平年値 $(8$ 年以上. 23 年以下の資料に基づく平均値）を作成して，解析 に用いた。ここでは，1990年から1999年までのう ち, 8 年以上データのそろっている811地点を日本 全土から抽出し, 対象地点とした. 久測の扱いは気 象庁 (1990)に準じた。 また, 気温データは特定日 の影響を受けていることが考えられるため，集計し て準平年値データとすることにより，その影響を除 去した.

\section{2 研究対象領域}

本研究では, 解析の目的別に, 以下に示す $3 \supset 0$ 研究対象領域を設定した。

\subsection{1 領域 1}

領域 1 (図 2 ) の範囲は, 北緯 34.0 度 38.5度, 東 経136.0度〜142.0度で，277の観測点が含まれる. 領域 1 では，バリオグラムにより空間代表性を求め るための方法を確立する. 4.3 節でバリオグラムに モデルを客観的に当てはめる方法を提案し，5.1節 で観測密度の影響を検討する。この範囲が設定され たひとつの理由として, 首都圏の熱環境の数值シミ ュレーションでは, この程度の範囲が解析対象とな るため, 本研究が数值モデル検証時の助けになるこ とを期待するためである.

\section{2.2 領域 2}

領域 2 (図 2)は，5. 2 節で, 領域の大きさによる バリオグラムの変化を調べるために用いる. 領域 2 は領域 1 の中心 (北緯36.25度, 東経 139.00 度)をバ ッファリングの中心とし，半径を変えた円として切 り出したものである. 図 2 の円はそれぞれ直径 $500 \mathrm{~km}, 700 \mathrm{~km}, 1000 \mathrm{~km}$ である.

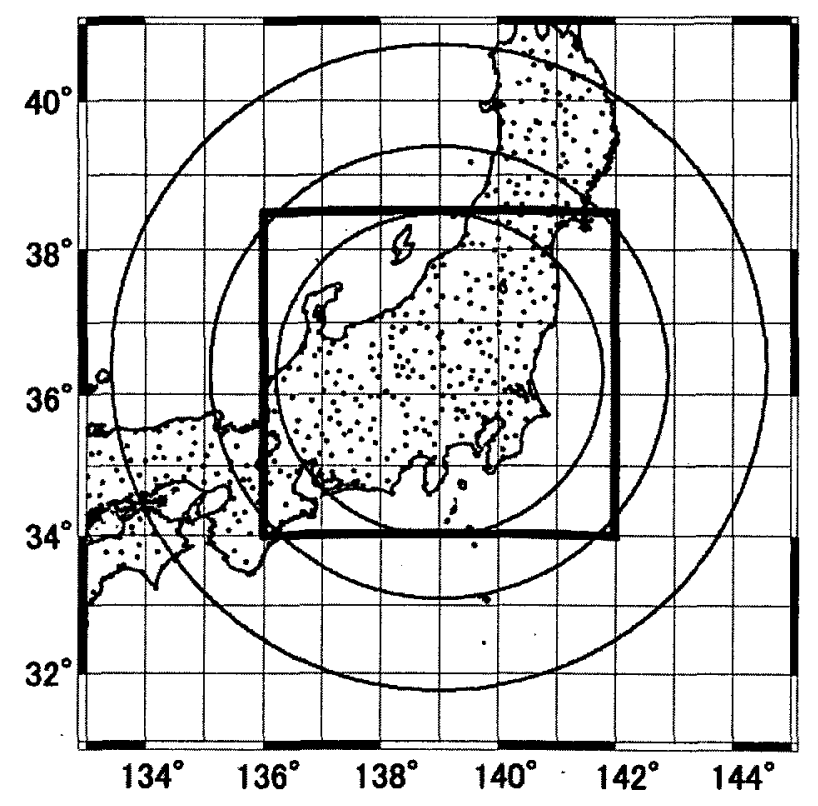

图 2 領域 1，領域 2 とAMeDAS観測地点 太矩形は領域 1，円の直径は $500 \mathrm{~km}, 700 \mathrm{~km}, 1000 \mathrm{~km}$. 


\section{2 . 3 領域 3}

領域 3 (図 3 )は, 5. 3 節において，5.2 節で示さ れることが他の領域でも成り立つかどうかを調べる ために, バッファリングの中心が異なる 4 つの地域 を設定したものである.

中心になる地点は，それぞれ 1) 北緯 43.0 度，東 経142.0度 (北海道)，2) 北緯38.5度, 東経140.0度 (東 北地方)，3）北緯34.5度, 東経133.5度 (瀬戸内地域), 4) 北緯 32.5 度, 東経 131.5 度 (九州)である。 それら を中心に, 領域 2 と同様に, 直径 $500 \mathrm{~km}, 700 \mathrm{~km}$, $1000 \mathrm{~km}$ の領域を切り出して領域 3 とした.

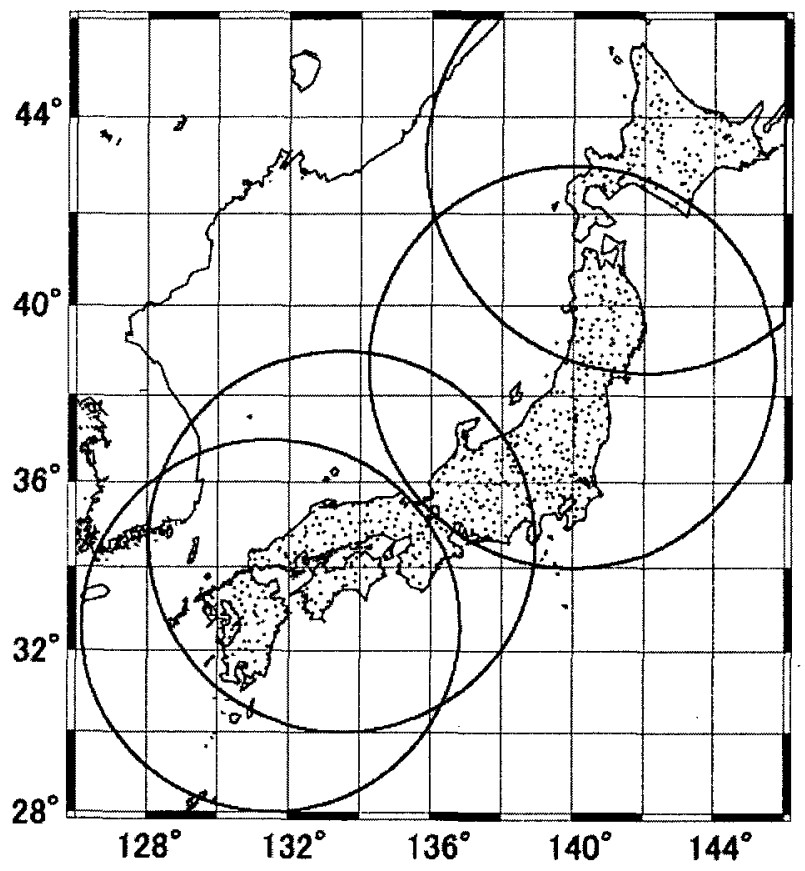

図 3 領域 3 とAMeDAS観測地点 円の直径はそれぞれ $1000 \mathrm{~km}$.

\section{4. 解析方法}

4. 1 傾向変動の除去

本研究ではバリオグラムは距離のみの関数でなく てはならない.しかし, 気温デー夕には緯度, 経度, 標高に依存する成分が多く含まれている，事前の解 析より, 領域 1 の277地点の気温デー夕は正規分布 で近似でき，外れ值もないことがわかっているが， これらを用いてバリオグラムを描くと(分割間隔 $10 \mathrm{~km}, 4.2$ 節参照)，図4のようになる.このバリ オグラムは図 1 の典型的なバリオグラムとは異なり, レンジも現れない，その原因は，領域 1 の気温デー
夕には図 5 のように緯度が高くなると気温が低くな る傾向があるからである，つまり，図 4 では，2地 点間の緯度の差と気温が強く関係しているために, 本研究で求めようとしているローカルな気温分布の 特徵を表現できなかったことになる．また，このデ ータセットには経度方向に傾向変動は存在しなかっ たが，例えば，領域 3 の北海道のように経度方向に 傾向変動が存在する場合もある.さらに, AMeDAS 気温データは現地気温であるために標高による影響 も受けている.もし，標高の影響を受けたままバリ

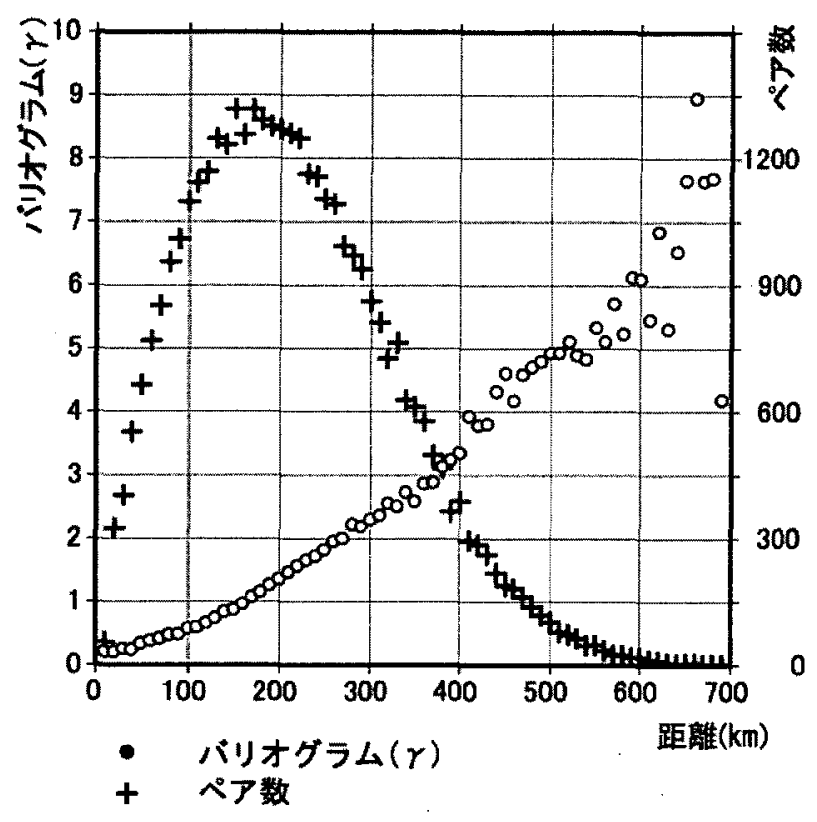

図 4 領域 1 における気温データのバリオグラム

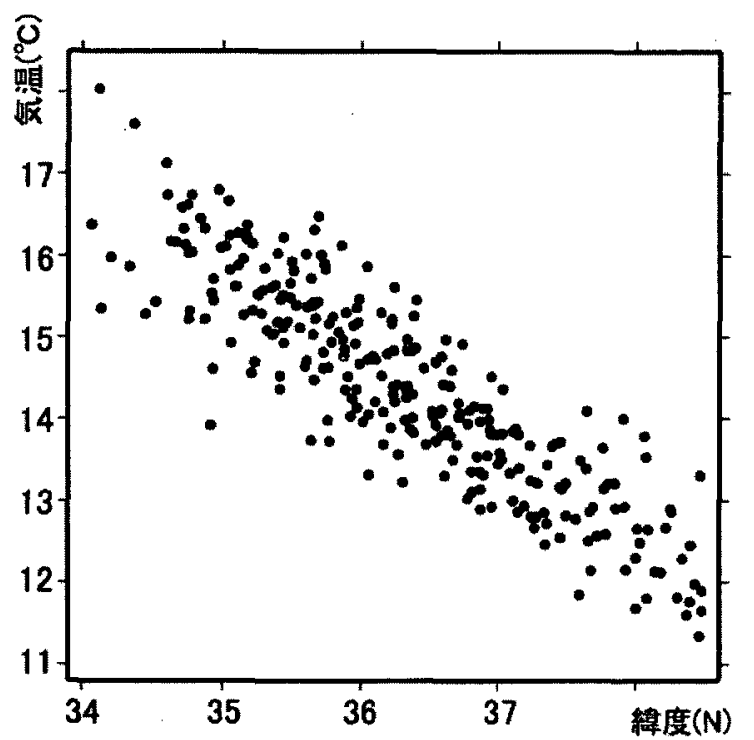

図 5 領域 1 における気温データの緯度-経度散布図 
オグラムを計算すると, 単に山地と平野の大きさを 表わすものになってしまう可能性がある. そこで, 本研究では, 次に述べる方法で, 位置の情報に依存 する成分を取り除くこととした.

取り除くべき位置の情報に依存する成分が 1 つの 時は, 図6のようにデータ $\mathrm{x}_{\mathrm{i}}$ からの距離 $\mathrm{d}_{\mathrm{i}}$ の総和 $\Sigma \mathrm{d}_{\mathrm{i}}$ を最小とする直線 $l$ を求める。，そこで，直線 $l$ を新たな座標軸(Chiles and Delfiner, 1999) と考え, 直線 $l$ と直交する成分 $\mathrm{d}_{\mathrm{i}}$ (以下, 「気温補正值」)につ いてバリオグラムを計算することとする，位置の情 報に依存する成分が 2 つ上上の時は，上述の方法を 多次元空間に拡張して，位置に依存する成分を取り 除くことができる.

また, 式(1)より明らかなように，バリオグラム は変数の 2 乗という単位を持つ. しかし, 上記のよ うに座標軸の変換を行うために, 本研究では, 単位 は意味を持たない，そこで本研究では，バリオグラ ムの縦軸には単位を付けないことにする.

5 章では多くのデータセットを作成して様々な考 察を行うことになる. 但し, 領域 1 のデー夕は緯度 と標高の影響を除去した「気温補正值」について, 5. 2 節以降ではすべてのデータセットについて緯度, 経度，標高の影響を除去した「気温補正值」につい てバリオグラムを作成する．このような例の等值線 図を図 7 に示す．この特徴については，5.2 節で詳 しく議論する。

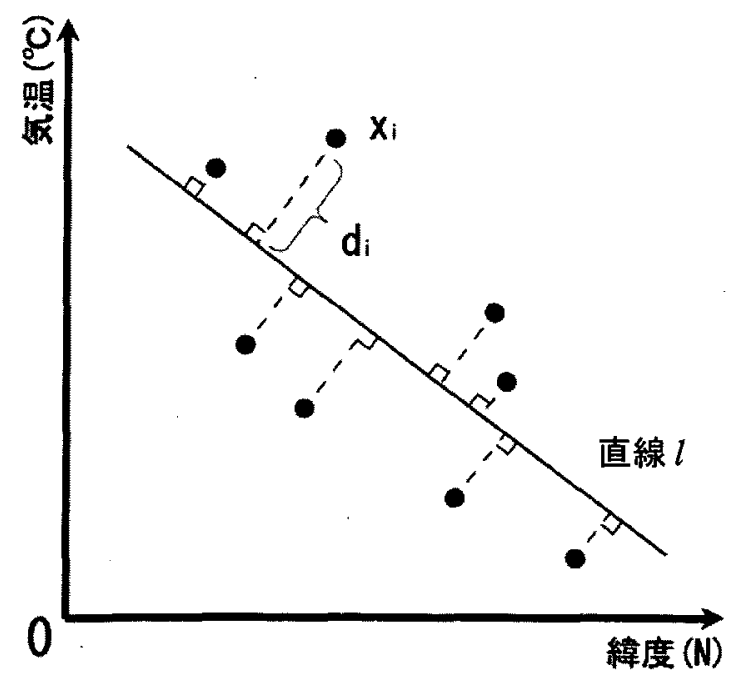

图 $6 \Sigma \mathrm{d}_{i}$ を最小とするような座標軸の変換に関する 模式図

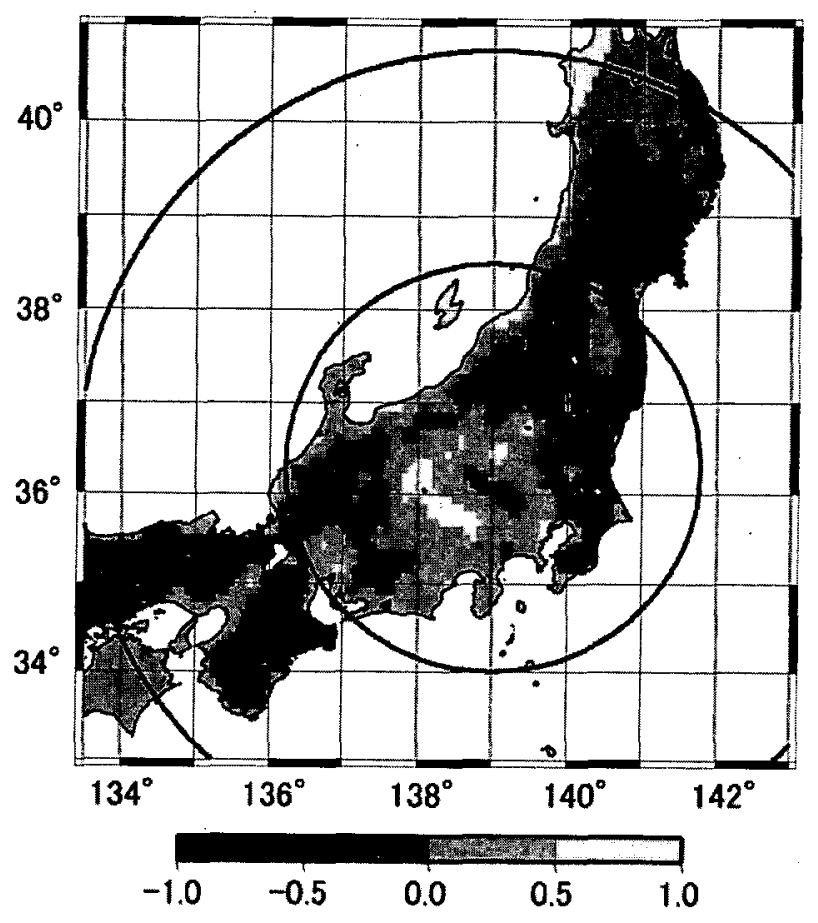

図 7 領域 2 のバッファ距離が直径 $1000 \mathrm{~km}$ 範囲に おける気温補正值の分布イメージ 円の直径は500km, $1000 \mathrm{~km}$.

\section{2 分割間隔の決定}

式(1)のhは分割間隔という幅を持った值である. ここで, 分割間隔 $10 \mathrm{~km}$ といった場合には, 地点ぺ ア間の距離が $10 \pm 5 \mathrm{~km}, 20 \pm 5 \mathrm{~km}, 30 \pm 5 \mathrm{~km} \cdots$ にあ るものを，それぞれまとめて扱うことを意味する.例 えば, 分割間隔が $10 \mathrm{~km}$ の時の $N(50)$ とは, 地点ぺ ア間の距離が $45 \mathrm{~km}$ 以上 $55 \mathrm{~km}$ 未満の地点ペア数を表 わす．領域 1 の傾向変動の除去済みデータを用い, AMeDAS地点の平均間隔を考慮し，分割間隔 5, 10, $20 \mathrm{~km}$ でバリオグラムを描くと図 8 のようになる. これらのバリオグラムに球型モデルを当てはめた時 のレンジはそれぞれ，294km，261km，282kmとな る. 分割間隔が大きいと原点付近の挙動が表現でき ず, 分割間隔が小さいとペア数が減少するためにバ リオグラムの変動が大きくなる (Liu et al., 2001). 図 8 より，分割間隔の違いによるレンジの差はほと んどないので, 本研究では分割間隔を $10 \mathrm{~km}$ として 解析を行う. 
(a)
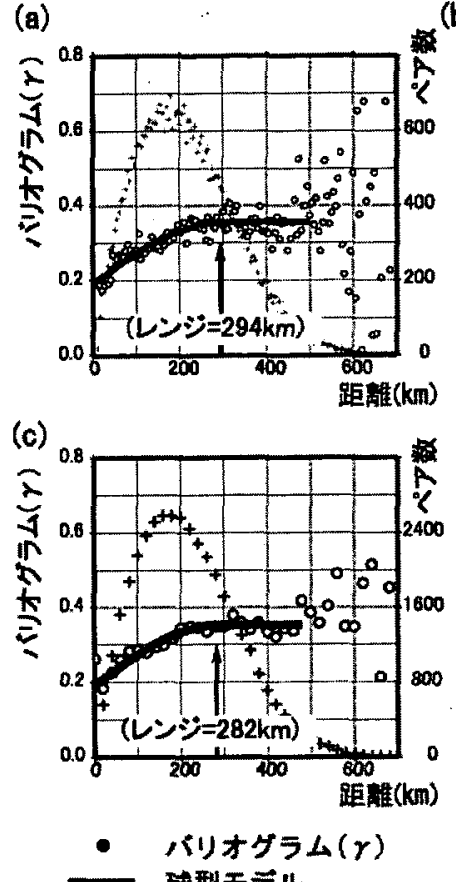

$+\begin{aligned} & \text { ペア型モデル } \\ & +\quad \text { 数 }\end{aligned}$ (b)

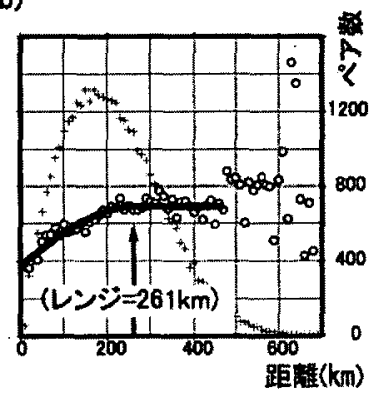

图 8 分割間隔による ハリリオ゙ラムの違い

(a) 分割間隔 $5 \mathrm{~km}$ の場合

(b) 分割間隔 $10 \mathrm{~km}$ の場合

(c) 分割間隔 $20 \mathrm{~km}$ の堨合

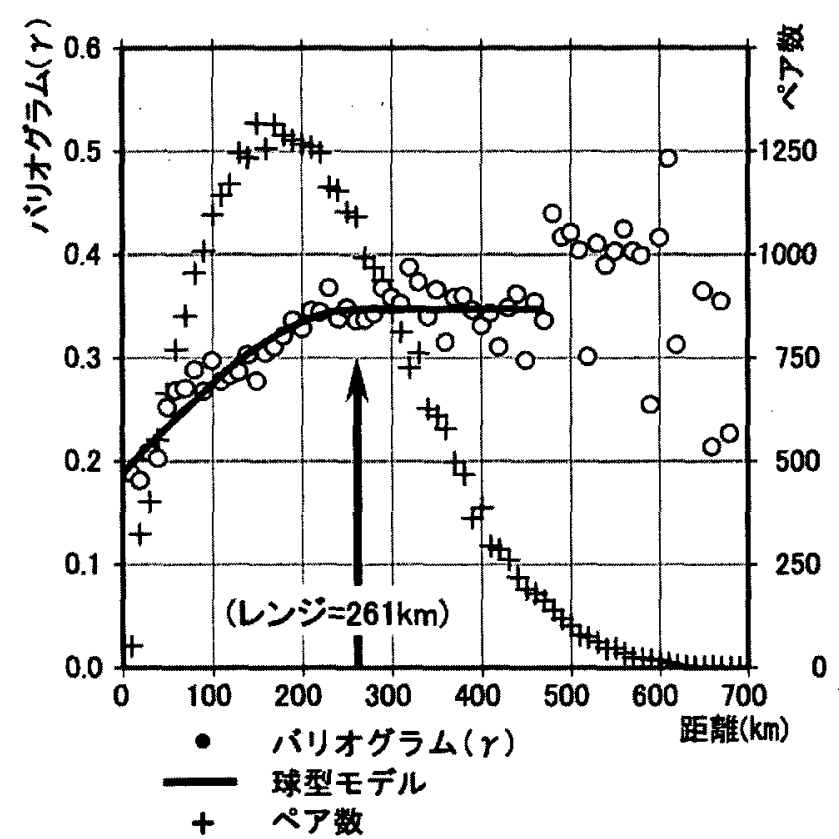

図 9 領域1における気温㭪正值のバリオグラムと ラページ検定を利用して当てはめた球型モデル

\section{3 モデル当てはめ距離の決定}

前節の方法で領域 1 の277地点のデータを処理し, バリオグラムを作成した(図 9)。このバリオグラム にはナゲット効果, シル, レンジが現れている. そ こで, 球型モデルを当てはめてレンジの値を求める. しかし，図 9 のバリオグラムでは距離約 $500 \mathrm{~km}$ 以上 で大きな変動が起きている．この原因として，距離 $500 \mathrm{~km}$ 以上でサンプル数が少なくなっており，その 結果, バリオグラムの值が安定しないことが考えら れる.このような場合, 大きな変動が起こる手前の 距離までにモデルを当てはめることが多い (Liu et al., 2001).

これまでの研究では，モデルをあてはめる距離は 主観的に決められてきた(間瀬・武田, 2001). そここ で本研究では，ラページ検定を利用してモデルを当 てはめる距離を客観的に決める方法を提案する. ラ ページ検定とは,「2つのグループの標本に対して それぞれの母集団の分布の位置のずれや散らばりぐ あいを同時に検定する」ものである(例えば，石村， 1989). ラページ検定統計量は，標本数がそれぞれ 10以上のときに自由度 2 の $\chi^{2}$ 分布に従うが, 最適 な標本数の決め方は確立されていない。 そこでここ では，標本数は各グループそれぞれ10とする.

本研究では分割間隔を $10 \mathrm{~km}$ としている.このた め, グループ 1 は, 距離 $\mathrm{n} \times 10 \mathrm{~km}$ から $(\mathrm{n}+9) \times 10 \mathrm{~km}$ の10個の $\gamma$ を指し，グループ 2 はグループ 1 につづ $<(\mathrm{n}+10) \times 10 \mathrm{~km}$ か $(\mathrm{n}+19) \times 10 \mathrm{~km}$ の10個の $\gamma の$ ことを指す。もし，グループ1とグループ 2 の検定 結果が「分布に差がある」となれば，グループ 2 に 相当する $(\mathrm{n}+10) \times 10 \mathrm{~km}$ 以降のバリオグラムは地点 ペア数が少ないために変動が大きくなっていると判 断し，(n+9) ×10kmまでにモデルを当てはめるこ とになる.

領域 1 の277地点のデータには, $10 \mathrm{~km}$ から690km

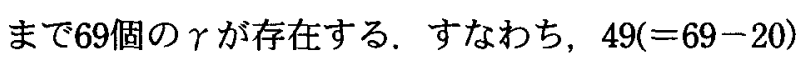
パターンについてラページ検定をおこない, モデル 当てはめ距離を決定する．その結果，「分布に差が ある」となった距離は $110 \mathrm{~km}$ か $210 \mathrm{~km} ま て ゙ と 470 \mathrm{~km}$ であった. バリオグラムがシルに達するまでの距離 (約 $250 \mathrm{~km})$ では, バリオグラムの值が変化しつづけ るので，「分布に差がある」という結果になってい る、また, $470 \mathrm{~km} て ゙$ 分布の差がある」となつたのは, 図 9 の約 $500 \mathrm{~km}$ 以上での大きな変動がラページ検定 によってとらえられたためである. そこで,ここで は470kmまでをモデル当てはめ距離とした，その結

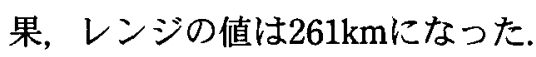


この結果, 客観的にレンジを決定することができ るようになった。 そこで, 上記のようなバリオグラ ムを用いた空間代表性の決定方法の汎用性を確認す るために, 次章では (1) 観測地点密度による影響, （2）領域の大きさによる影響，（3）領域の違いによ る影響の3点について解析と考察を行う.

\section{5. 結果・考察}

\section{1 観測地点密度による影響}

観測地点密度がバリオグラムに与える影響をみる ために，領域 1 の277地点をもとに観測地点をラン ダムサンプリングしたデータセットを作成した. こ こで, 対象領域の面積は不変であるので観測密度と 観測地点数は同義である.

観測地点のサンプリングの仕方によっては, 分布 パターンが集中分布になる可能性がある. 一極集中 になる場合, バリオグラムは観測地点が集中したそ の領域におけるものになる.これは，対象領域を小 さくしたことと同義である. そこで，意図的に集中 分布の作成を試みたところ, 観測地点数を 60 地点 にすると有意水準 $1 \%$ でランダム分布との差が認め られた. つまり, 観測地点数を60地点以下にする と集中分布になる可能性が生じる. そこで, ランダ ムサンプリングするデータセットの最小観測地点数 を61地点とし，その他に $120,180,240$ 地点のもの をそれぞれ10セットずつ，計40セット作成した.

ただし，観測地点が少なくなって，観測気温が代 表する空間スケールより地点間距離が長くなると, バリオグラムにレンジが現れなくなることが容易に 想像できる. 領域 1 のAMeDAS観測地点の平均最近 隣距離は約 $17.2 \mathrm{~km}$ である. 観測地点数を $1 / \mathrm{n}$ 倍に すると, 平均最近隣距離は地点間隔の理論值の $\sqrt{n}$ 倍になる(奥野, 1977)ので(但し, 領域 1 では 海域が存在するのでこれによらない), 観測地点数 61でも, 地点間距離は観測気温が代表する空間ス ケールより長くなることはないと考えられる.

図10は観測地点数とレンジの関係を示したもの である. バーは標準偏差を表わしている. ラページ 検定で母集団の差の検定を行ったところ，各データ セット間で有意水準 $1 \%$ 差はなかった.つまり,
この解析から，観測気温が代表する空間スケールよ り観測地点間隔が十分小さい場合, 空間代表性は観 測地点密度の違いによらないことが明らかになった。

また，バリオグラムの示すレンジは，無視できな い程度の標準偏差をもっていることが分かる(図10). それゆえ,バリオグラムを用いた解析をする時には， レンジがこのように幅をもつた值であることを考虑 する必要がある.

本研究では, 図10の標準偏差の平均は約60kmで あった. そこで, 277 地点でのレンシ $261 \mathrm{~km}$ 活 $60 \mathrm{~km}$ 程度の標準偏差を持つた值であると解釈する.

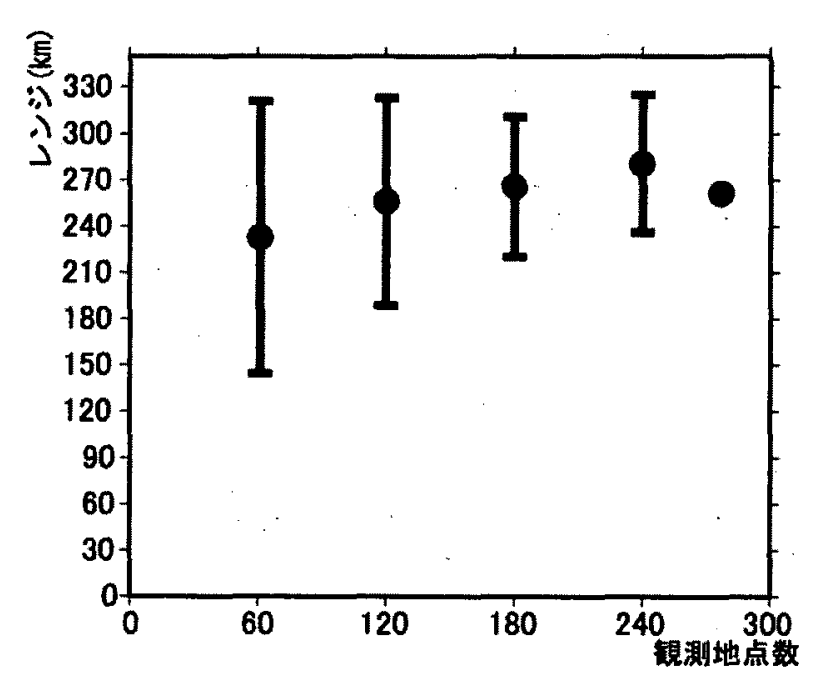

图10 領域1における観測地点数とレンジの関係 バーは標準偏差.

\section{2 領域の大きさによる影響}

ここでは，領域 2 を対象として領域の大きさがバ リオグラムに与える影響について調べる。図11は(a) 直径 $500 \mathrm{~km}$ と(b)直径700kmのバリオグラムである. 直径 $500 \mathrm{~km}$ のバリオグラムはレンジが $114 \mathrm{~km}$ であり, 直径 $700 \mathrm{~km}$ ではレンジが $272 \mathrm{~km}$ であった. 5.1 節で, 領域 1 の場合, レンジは $\pm 60 \mathrm{~km}$ 程度の幅を持った 值であることを示したが, 直径 $500 \mathrm{~km}$ と直径 $700 \mathrm{~km}$ のバリオグラムのレンジの差は標準偏差では説明で きない。 そこで, 直径 $700 \mathrm{~km}$ のバリオグラムの $100 \mathrm{~km}$ 近辺に注目する.すると, 微妙ではあるが

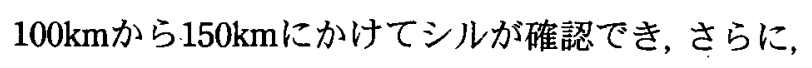
$300 \mathrm{~km}$ から 2 つのシルが存在しているように見え る. Chiles and Delfiner(1999)では, 複数の異なつた スケールの現象が混在するとき, レンジが多重構造 
(nested structure)をなすとしており，図11-(b)もこ のような構造が現れていると考えられる.
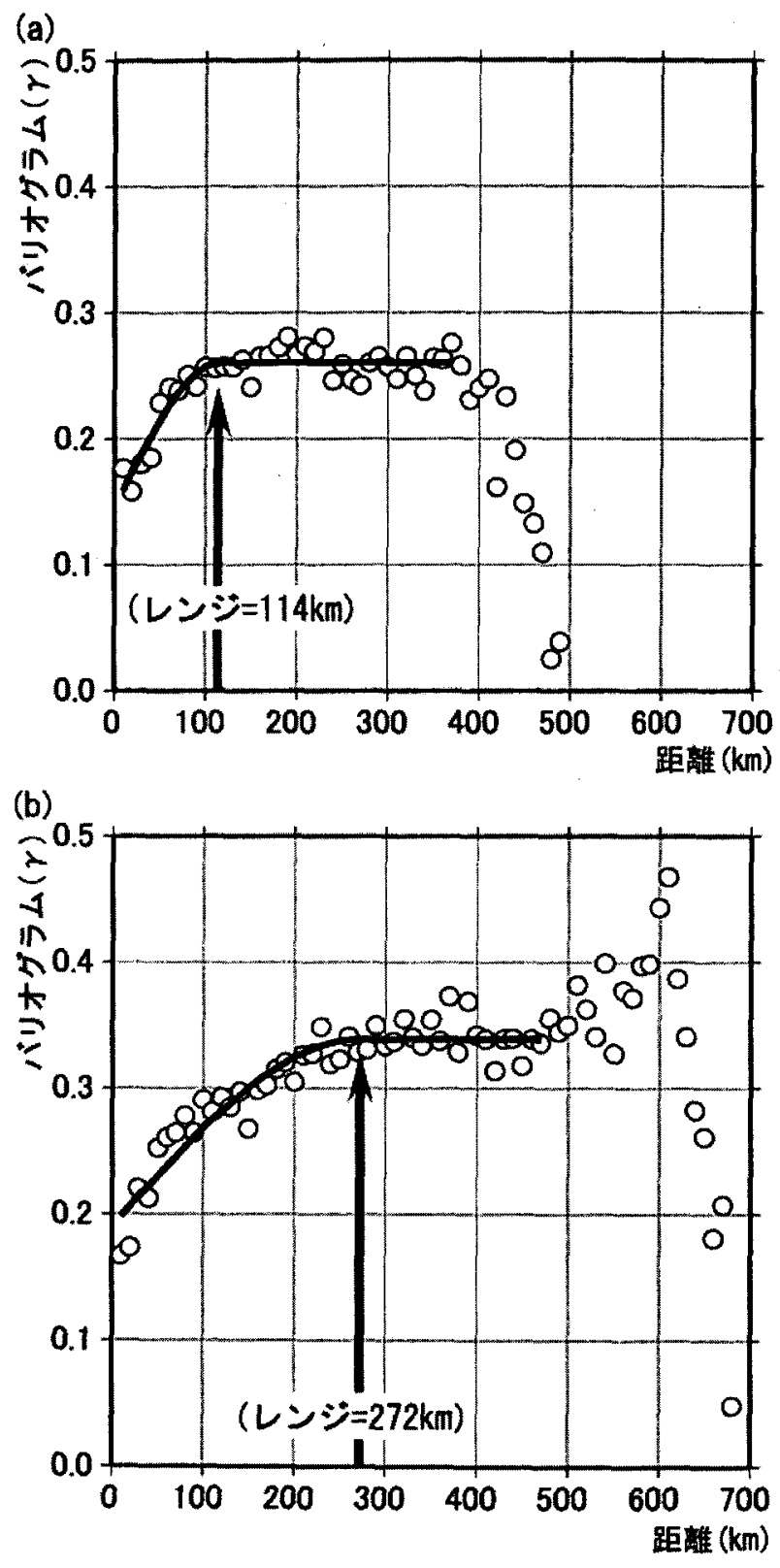

図11 領域 2におけるバリオグラム
(a) 直径 $500 \mathrm{~km}$
(b) 直径 $700 \mathrm{~km}$

そこで，二重になったレンジを検出する方法とし て, 次のような方法を提案する，まず，ある距離ま

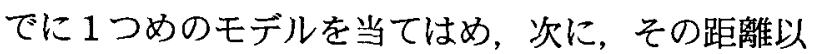

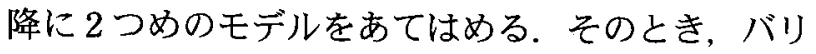
オグラムによる $\gamma$ と, モデルによる $\gamma$ の相関係数 を求める. 距離を次々に変化させ, 最も相関係数の よい距離を最適分割距離とする.

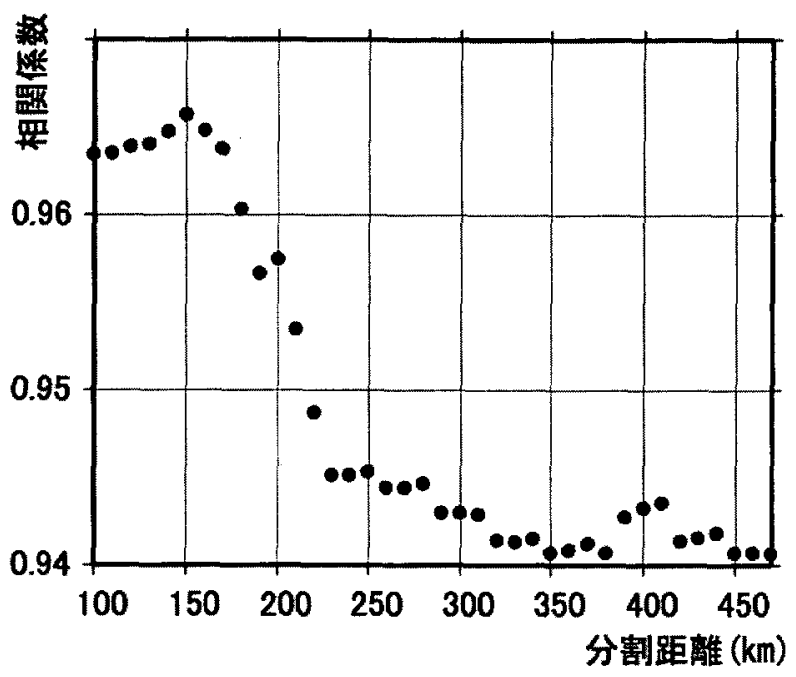

図12 領域 2 で,バッファ距離が直径700kmの範囲に おけるバリオグラムの二重構造を検出するた めの相関係数と分割距離の関係

直径700kmのバリオグラムについて上記の方法で 最適分割距離を求め(図12)，図11-(b)に重ねた（図 13). 1 つめのレンジは $98 \mathrm{~km}, 2$ つめのレンジは

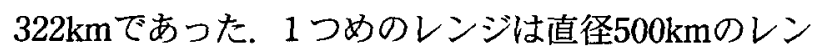
ジ $(114 \mathrm{~km})$ にかなり近い.さらに，領域を大きくし て直径1000kmのバリオグラムを作成すると(図14), 距離約 $100 \mathrm{~km}$ にずかに変曲点が確認でき，上記の 方法で 1 つめのレンジを $126 \mathrm{~km}, 2$ つめのレンジを $196 \mathrm{~km}$ として検出できた。 しかし，領域を大きくす ることで，バリオグラムは小さなスケールの現象が 次第に表現できなくなり，より大きなスケールの現 象が目立つようになることがわかる(図14).

また，図14に示した直径 $1000 \mathrm{~km}$ のバリオグラム

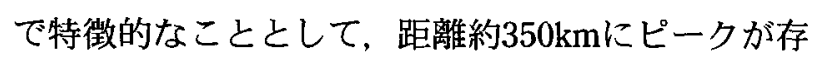
在し，それ以降ではバリオグラムの值が減少し, 距 離約600kmから約 $900 \mathrm{~km}$ ではバリオグラムの值がほ ぼ一定になることが挙げられる。このような形のバ リオグラムは，図1に示した典型的なバリオグラム とは異なるし，また，これまでの研究には見られな いものである. しかし，典型的なバリオグラムと同 様に，バリオグラムが一定であるところはシルであ りそそれに達する距離はレンジであると考えられる。 この場合，元デー夕は近距離で近い值，中距離で遠 い值, 遠距離で近い值をとるという空閒配置をして いると考えられる. 


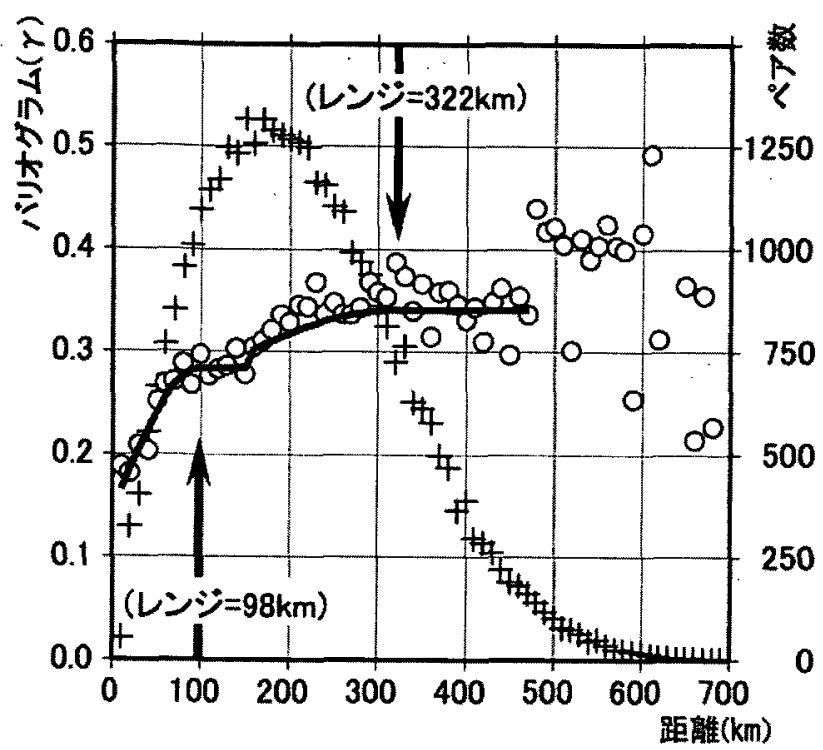

図13 領域 2 でバッファ距離が直径700kmの範囲に おけるバリオグラムに当てはめたニ重モデル

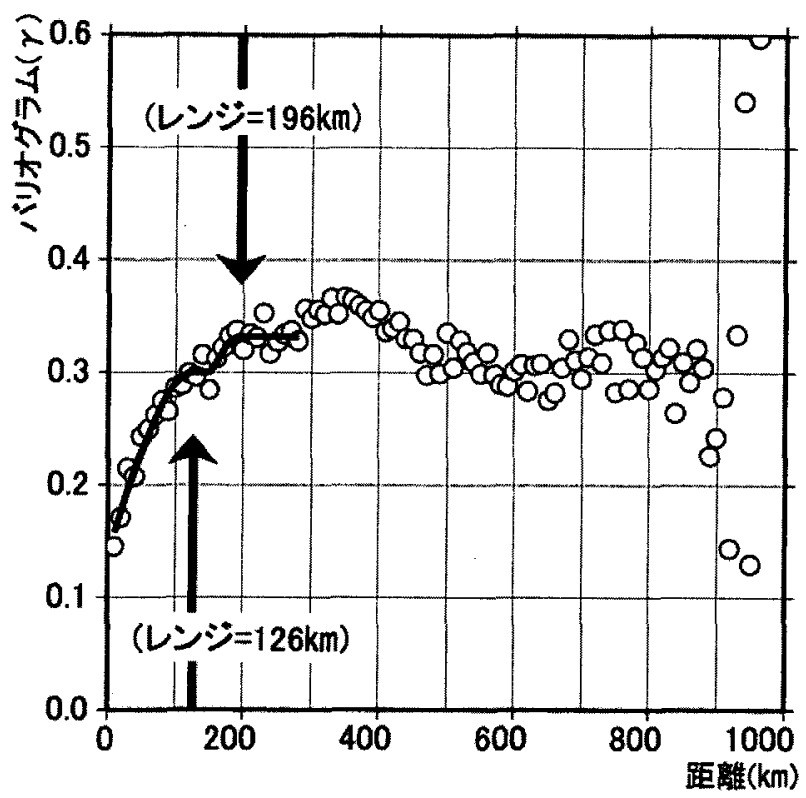

図14 領域 2 のパッファ距離が直径1000kmの 範囲におけるバリオグラム

そこで，この仮説を検証するために人為的にデー 夕(以下このデータを実験データと呼ぶ)を作成して 検討を行った。実験データは図15のようであり，左 右のメッシュには $1 \sim 6$, 中央のメッシュには 7 12の整数が，それぞれランダムに100個ずつ格子状 に入力されている.この実験データを元にバリオグ ラムを描いたところ(図16)，一度ピークが現れ(距 離約10１2)，減少した後に安定する(距離約 20 以
降）という形が再現された。つまり，この実験デー 夕は図16のようなバリオグラムを与えるものの $1 つ$ と考えられる.

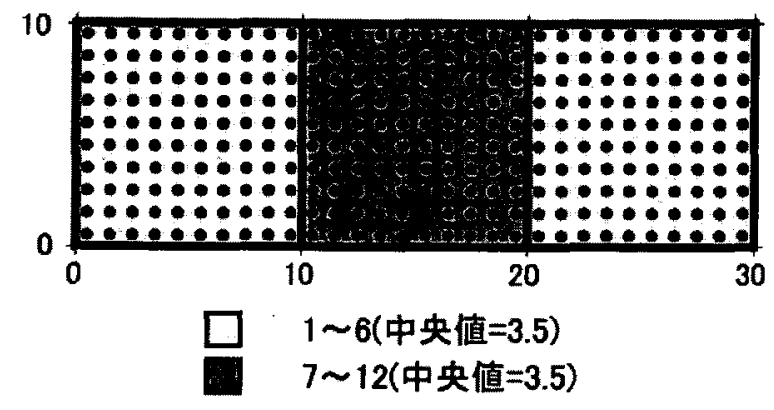

図15 実験データのイメージ

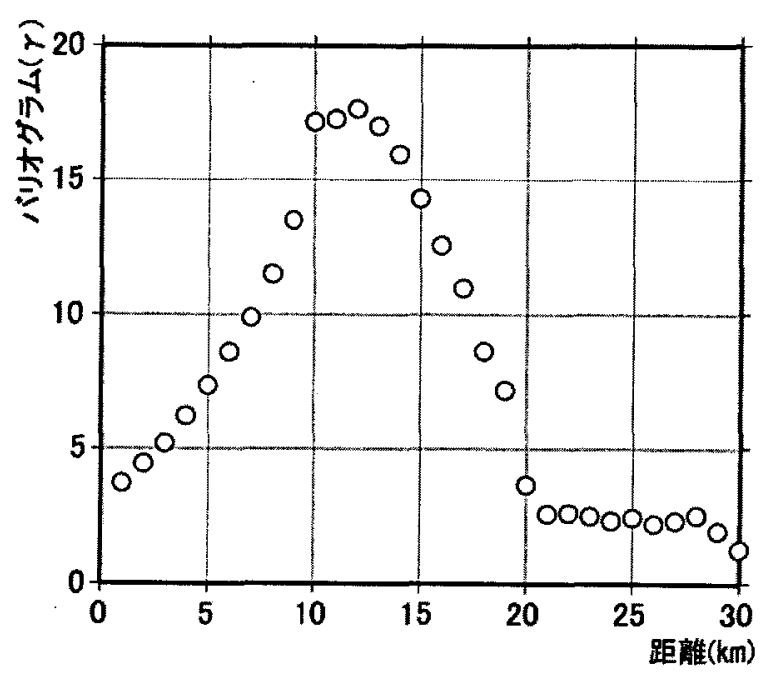

図16＼cjkstart実験データにおけるバリオグラム

ある程度離れた地点ペアの方が気温差が小さいと いうのは一見イメージしづらいが, 本研究では緯度, 経度, 標高の影響を取り除いた「気温補正値」につ いて解析をしているため，このような現象が起きて いると考えられる. 気温補正值の等値線図 (図 7) か ら，地点間距離が $600 \mathrm{~km}$ 以上では同色のものが多く， 地点間距離が $350 \mathrm{~km}$ 程度では異色のものが多い傾向 が読みとれる，逆に，そのことを客観的に表わして いるのが図14のバリオグラムであると言える。こ のことは直径 $1000 \mathrm{~km}$ の領域を対象とした場合， $350 \mathrm{~km}$ と $600 \mathrm{~km}$ 程度の空間代表性を持つ大気現象が 多重構造をなして，気温の空間分布に影響を与えて いることを意味している. 


\section{3 領域の違いによる影響}

この節では，前節で得られた知見が他地域でも成 り立つかどうか，領域の違いによる影響について検 討を行う。

\section{1 ) 北海道 (図17)}

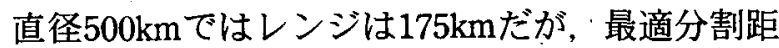
離110kmで分割すると1つめのレンジは72km，2つ めのレンジは $180 \mathrm{~km}$ である (図17-a)，また，直径 $700 \mathrm{~km}$ では，距離 $500 \mathrm{~km}$ までのバリオグラムの形は ほとんど変化せず，レンジは約250kmである(図17b). そこで，最適分割距離 $110 \mathrm{~km}$ で分割すると $1 つ$ めのレンジは約 $90 \mathrm{~km}, 2$ つめのレンジは約 $250 \mathrm{~km}$

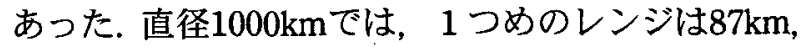
2 つめのレンジは $254 \mathrm{~km}$ であり, 距離 $500 \mathrm{~km}$ でバリ オグラムが減少し，その後安定するのが顕著である (図17-c).
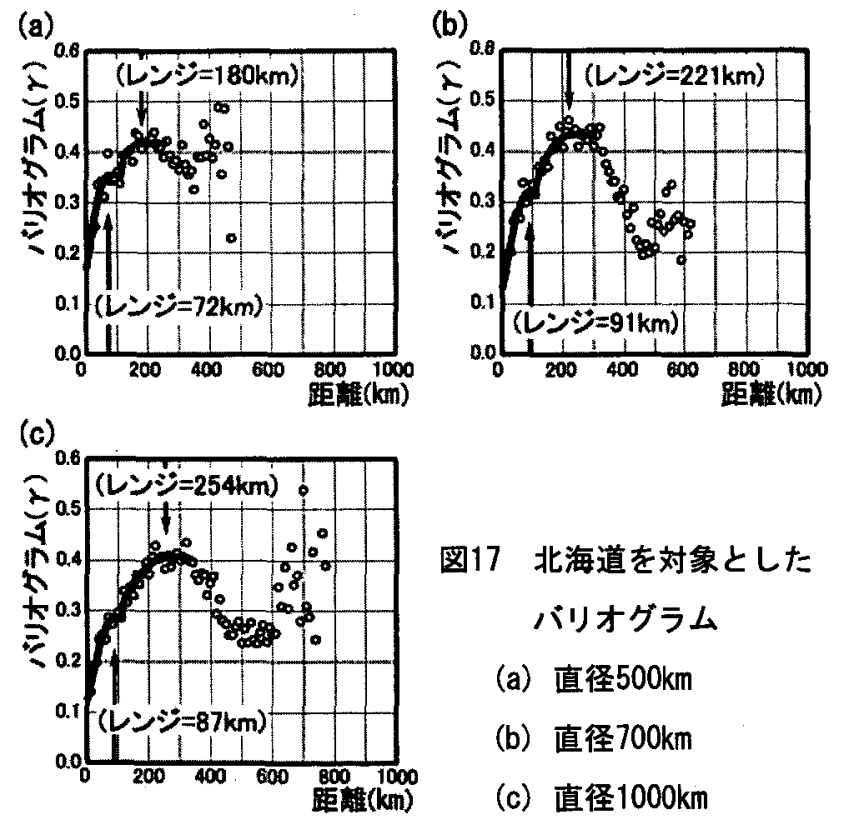

图17 北海道を対象とした バリオグラム
(a) 直径 $500 \mathrm{~km}$
(b) 直径 $700 \mathrm{~km}$
(c) 直径 $1000 \mathrm{~km}$

\section{2 ) 東北地方 (図18)}

直径500kmではレンジは100kmである（図18-a）。 直径 $700 \mathrm{~km}$, 直径 $1000 \mathrm{~km}$ では約 $200 \mathrm{~km} に な る$ (図18b，c）。しか值径 $700 \mathrm{~km}$, 直径 $1000 \mathrm{~km}$ では，直径 $500 \mathrm{~km}$ のレンジに相当するようなレンジは検出でき なかった。また，直径 $1000 \mathrm{~km}$ では距離 $500 \mathrm{~km}$ $600 \mathrm{~km}$ でバリオグラムが減少して安定する傾向がわ かる(図18-c).
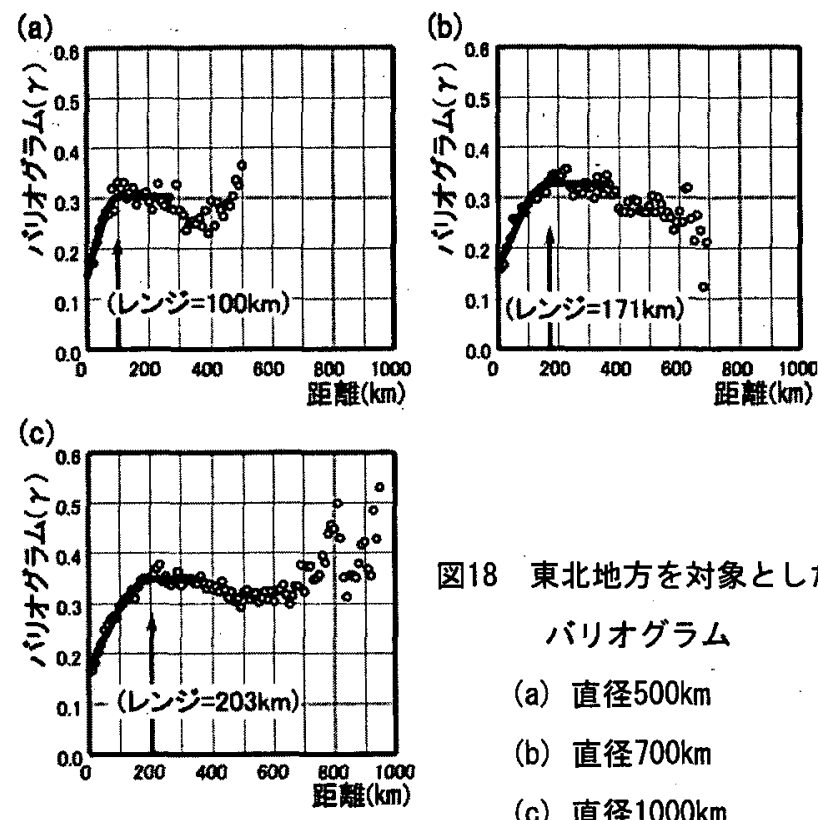

図18東北地方を対象とした パリオグラム
(a) 直径 $500 \mathrm{~km}$
(b) 直径 $700 \mathrm{~km}$
(c) 直径 $1000 \mathrm{~km}$

\section{3 ) 瀬戸内地域 (図19)}

直径 $500 \mathrm{~km}$ ではレンジは170kmであるが(図19-a)， 最適分割距離の検出はできなかった．直径 $700 \mathrm{~km}$ は球型モデルを当てはめることはできなかった(図 19-b). また，この地域では領域を大きくしても図 1 で示した典型的なバリオグラムの形を保っている (図19-c). 直径1000kmではレンジは136kmである.
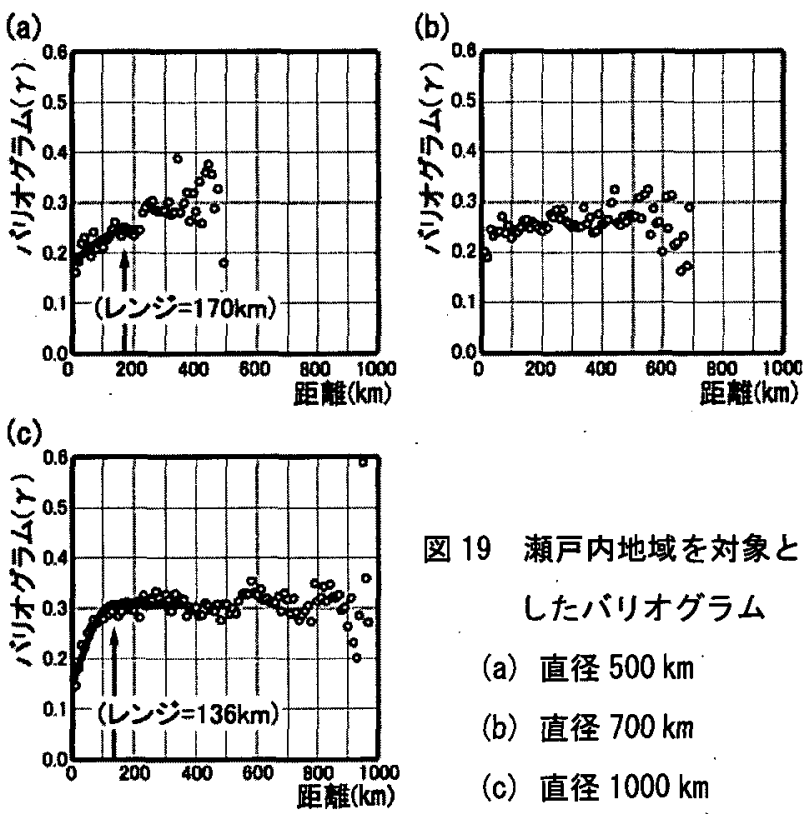

図 19 瀬戸内地域を対象と したパリオグラム
(a) 直径 $500 \mathrm{~km}$
(b) 直径 $700 \mathrm{~km}$
(c) 直径 $1000 \mathrm{~km}$

\section{4 ) 九州(図20)}

直径500kmではレンジは61kmである(図20-a)，ま 
た，直径 $700 \mathrm{~km}$ では最適分割距離 $140 \mathrm{~km}$ で分割する

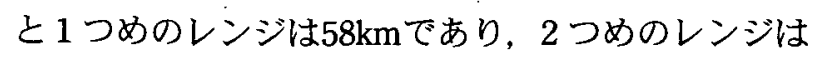
$150 \mathrm{~km}$ である (図20-b) : 直径 $1000 \mathrm{~km}$ では球型モデ ルを当てはめることはできなかった(図20-c).
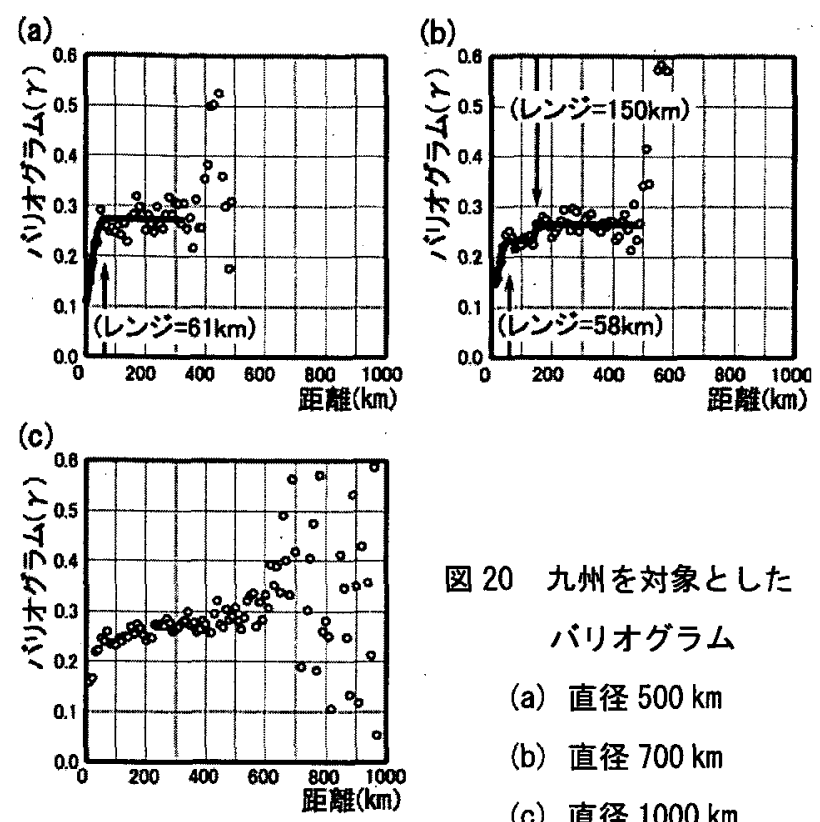

図 20 九州を対象とした バリオグラム

(a) 直径 $500 \mathrm{~km}$

(b) 直径 $700 \mathrm{~km}$

(c) 直径 $1000 \mathrm{~km}$

上記の 4 領域で得られた結果をまとめると以下の ようになる.

・領域によってバリオグラムの形は変化するが, ほとんどの場合，4 章や 5.2 節の解析方法を 適用することができる.

・多少の地域差があるものの, 1つめのレンジは

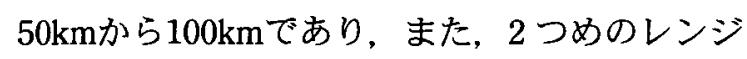
は $150 \mathrm{~km}$ か $300 \mathrm{~km}$ である.

・ 対象とする領域を大きくすると，ほとんどの場 合, 多重構造が見られる.つまり，バリオグラ ムには様々なスケールの大気現象が現れている.

\section{6. 結論}

6. 1 本研究で明らかになったこと

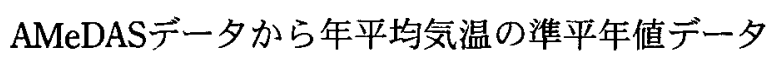
を作成し，それを元にバリオグラムを描き，気温の 空間代表性を明らかにした。その結果, AMeDAS気 温準平年值データは最小で $50 \mathrm{~km}$ から $100 \mathrm{~km}$ 程度の 空間代表性があることが分かった.

このことを明らかにするにあたってバリオグラム
から気温の空間代表性を示すための手法を確立した.

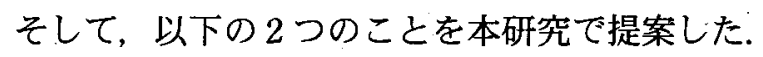

1）ラページ検定を利用することで球型モデルの当 てはめ距離を客観的に決定できる.

2 ）二重構造をなすバリオグラムは球型モデルを 2 段にすることで検出できる.

また，上記の方法の汎用性を検証したところ，次の ことが明らかになった.

・ バリオグラムが示す空間代表性は観測地点密度 の影響を受けない.

・対象領域を大きくするとバリオグラムは多重構 造をなす。これは，様々なスケールの大気現象 が存在するためであると考えられる.

・ バリオグラムの形は対象とする領域ごとに異な る.これは領域ごとに大気現象やそのスケール が異なることを意味していると考えられる。

\section{2 今後の課題と展望}

本研究では気温の空間代表性を客観的に示すた めに，様々な基準や統計的指標を用いた. しかし， いくつか主観的判断で決定した基準もある. 例えぼ, 4.2 節で分割間隔を $10 \mathrm{~km}$ と決めたが, Liu et al. (2001)では, 分割間隔の重要性が指摘されている. また, ラページ検定の際, 標本数が10以上であれ ばラページ検定統計量は自由度 2 の $\chi^{2}$ 分布に従う ため, ここでもグループの標本数を10としたが, その根拠は弱く, 今後標本数に関する検討が必要と 考えられる.

バリオグラムの多重構造は領域を大きくすると検 出が困難になる．しかし，見えそうで見えないもの を客観的に表わすことが地理情報学を含む科学全般 の命題である.このため, 多重構造の客観的評価に はさらなる検討が必要と考えられる.

また，大気現象の時間スケールと空間スケールに は密接な関係がある(例えば小倉, 1999)。したがっ て, 気温の空間代表性は使用する気温デー夕の平均 期間に大きく依存する可能性がある。そのため, 気 温データの平均期間と気温の空間代表性の関係を検 討することが必要だろう.

近年注目されている都市気候の解析に用いられる 
気象データには大きな局所的影響が含まれている可 能性がある。つまり，このようなデータの空間代表 性は非常に小さいことが予想される，気象観測地点 の間隔がその気象要素の代表する空間スケールより 大きい場合，それは観測地点が不足していることを 意味する. そのため, 本研究の手法を都市気候スケ 一ルへ適用することで, 都市気候の観測計画や解析 の一助になることが期待できる.

\section{謝辞}

本研究を進めるにあたって，有益なご助言をいた だいた東京工業大学工学研究科の間瀬 茂先生にお 礼申し上げます。

なお，本稿は，第一筆者が2003年 2 月に，東京都 立大学理学部地理学科に提出した卒業論文をまとめ たものである.

\section{参考文献}

石村貞夫（1989）『統計解析のはなし』，東京図書。

泉岳樹 ·岡部篤行 - 貞広幸雄・花木啓祐・一ノ瀬俊明 （1999）首都機能移転による熱環境变化の予測.「環
境システム研究」, 27, 171-178.

奥野隆史（1977）『計量地理学の基礎』，大明堂.

小倉義光（1999）『一般気象学 第2 版』, 東京大学出版 会.

気象庁（1990）『地上気象観測統計指針』, 気象庁.

日本気像学会編（1998）『気象科学事典』, 東京書籍.

間瀬茂・武田純（2001）『空間データモデリング一空間統 計学の応用』，共立出版.

三宅䐝（1973）雨量観測点の密度と面積雨量の観測精度, 「水利科学」, No.93, 57-71.

Chiles, J.P., and Delfiner, P. (1999) Geostatistics. New York: John Wiley \& Sons.

Liu, S., Mo, X., Li, H., Peng, G., and Robock, A. (2001) Spatial variation of soil moisture in China Geostatistical characterization, Journal of the Meteorological Society of Japan, 79, 555-574.

Sugawara, H. (2001) Heat exchange between urban structures and the atmospheric boundary layer. Doctoral dissertation, Department of Geophysics, Tohoku University.

原稿受付：2003年 4 月 28 日

採用決定：2004年 5 月25日 